DOI: $10.17805 /$ trudy.2018.2.4

\title{
К ВОПРОСУ О КАЧЕСТВЕ РОССИЙСКОЙ ПОСТСОВЕТСКОЙ ФИЛОСОФИИ
}

\author{
В. Ф. Дружинин \\ Независимый автор, г. Москва
}

Аннотация: В статье автор размышляет о новом качестве современной российской философии, о проблемах, которые стоят перед ней и о миссии философов.

Текст доклада автора на Всероссийской научной конференции «Культура между Логосом и Мифом: к проблеме бессознательного (к 80-летию А.Э. Воскобойникова)», которая прошла в Московском гуманитарном университете 26-27 октября 2017 года.

Ключевые слова: философия; отечественная философия; современность

\section{ON THE ISSUE OF THE QUALITY OF RUSSIAN POST-SOVIET PHILOSOPHY}

\author{
V. F. Druzhinin \\ Independent Author, Moscow
}

Аннотация: In his paper the author ponders on the new quality of modern Russian philosophy, on the issues that it is facing, and on the philosophers' mission.

The text of the author's speech at the All-Russian Scientific Conference "Culture between Logos and Myth: on the Issue of the Unconscious (dedicated to the 80th anniversary of A. E. Voskoboynikov)", which was held at Moscow University for the Humanities on 26-27 October 2017.

Ключевые слова: philosophy; domestic philosophy; modernity

Статья подготовлена к юбилею известного философа и педагога А.Э. Воскобойникова, с которым наши творческие пути пересеклись еще в «лихие девяностые». Нас объединял интерес к философским проблемам психологии, который не утрачен и по сию пору, о чем свидетельствует довольно частое присутствие самого профессора, его студентов и аспирантов, на круглых столах «Философские диалоги», которые я регулярно провожу в Центральном Доме литераторов, в 000 «Библио-Глобус».

Сегодня философия у нас находится на перепутье: само понятие «философия» слишком долго в нашей стране было чрезмерно заидеологизированным, заангажированным и часто до сих пор воспринимается многими 
Научные труды Московского гуманитарного университета 2018 № 2

негативно, узко, как всего лишь марксистско-ленинская философия советского образца; мыслителей глубоких, ярких, самобытных что-то не видно (результаты Российских философских конгрессов об этом свидетельствуют, в частности); поиск их за рубежом также не дает позитивных результатов (об этом говорят итоги философских конгрессов - уже всемирных).

Возникает вопрос, как быть дальше, куда идти?

Достаточно адекватным ответом на этот вопрос является, на мой взгляд, творчество А. Ф. Лосева, в частности, его «Диалектика мифа» (Лосев, 1930). Как тут не вспомнить его философию «высшего синтеза», «философию всеединства», провозвестником которой он был еще в СССР. Как пишет в предисловии к «Диалектике мифа» А. А. Тахо-Годи, уже «в юности А. Ф. Лосев написал сочинение «Высший синтез, как счастье и веденье» (1911). Здесь им выдвигается принцип единства науки, философии, религии, искусства и нравственности, которое и составляет высший синтез духовной жизни человека... И для зрелого Лосева идея «всеединства и высшего синтеза» неизменно актуальна». Действительно, «великий синтез» - мечта, которую стремились воплотить интеллектуалы высочайшего класса в истории философии: древняя Индия, Персия, Египет, Израиль, - далее Европа - от Платона до современности, в т. ч. и в дореволюционной России. (Кстати, Ф. Шеллинг в 19 лет также написал «эй кан пан» - «все едино»; — в конце жизни он пишет сыну: «Лессинг сказал «все едино» и я не знаю ничего, сказанного лучше», — из предисловия к собранию сочинений Шеллинга).

А. Ф. помнил об этом. Но многие в его и наше время забыли (или делали, делают, вид, что забыли). Теперь, похоже, настала пора вспомнить и нам. Правда, есть одна важная деталь: А. Ф. в конце пути (по крайней мере, в пору написания «Философии имени» (1923) и основного содержания «Диалектики мифа» (1927), завершаемого (гл. XIII), видит «имяславие» (Похоже, именно поэтому С. С. Хоружий характеризует его творчество, как «арьергардный бой русской христианской культуры» (там же: 30)).

Но это не вся правда. А. Ф. позднее указывает на понимание «философии» с позиции синтеза всего знания, наработанного человечеством за многие тысячелетия его существования, т. е. с позиции интеграции и научного знания, и религиозно - мифологических установок, и интуиций искусства различных направлений, и мистических прозрений, о чем свидетельствуют его размышления об «абсолютной мифологии» (гл. XIV — как дополнение из рукописей). И, на мой взгляд, правильнее говорить об «авангардном бое» замечательного философа в суровые советские времена. Но вот в чем вопрос: уже и завершилась пора репрессий, уже и А. Ф. реабилитирован, - ему присуждена Государственная премия и он даже награжден орденом, - уже существует его Дом - музей (библиотека) в центре Москвы, но преемники 
«философии высшего синтеза» что-то не просматриваются явно. Похоже, Левиафан (государственная идеология т. н. марксизма-ленинизма, вбитая в головы философов СССР, - «одичавшие философы», по остроумному выражению А. Ф.) отнюдь не побежден, - в головах наших философов он существует, похоже, на генетическом уровне. Он слишком изворотлив, он обладает страшным оружием, - «замалчивание». Поэтому, на мой взгляд, столь важна работа Дома - музея (библиотеки), работникам которого хочется пожелать дальнейших успехов в пропаганде творческого наследия Мэтра. И возможно, наконец, этот тренд скажется на работе наших философов, в том числе и в ходе конгрессов, всероссийских и мировых.

Моя новая книга «Как жить человеку на планете Земля?» (Дружинин, 2015), - как раз об этом. Сегодня второе издание книги (с изменениями и дополнениями) выполнено немецким издательством Lambert Academic Publishing (2017).

В подзаголовке книги указано, что это «Философские диалоги», что указывает на происхождение и структуру книги, выросшей из круглых столов, которые я провожу последние годы в Центральном Доме Литераторов в Москве и в Библио-Глобусе, одном из крупнейших книжных магазинов столицы.

В рамках этих круглых столов мною начата и выполняется с 2013 г. большая образовательно-просветительская тема «Отцы и дети европейской философии». Предполагается (и постоянно реализуется) достаточно подробный анализ творчества крупнейших представителей интеллектуальной элиты Европы (от Платона до современности), а также древней Индии и Персии, при оценке которого идет разворот от чрезмерной заидеологизированности советского периода к выделению традиционных мотивов философии всеединства и высшего синтеза. (Кстати, я стремлюсь также особо выделить произведения авторов, которые ранее назывались в числе т. н. материалистов, но некоторые их концепции и точки зрения затушевывались, искажались, не упоминались (по идеологическим мотивам), даже если они и существовали, - Демокрит, Эпикур, Л. Кар, Д. Локк, Т. Гоббс и некоторые другие).

В целом, движение мысли автора в книге идет, как можно заметить, от наиболее общих размышлений о «бытийной сущности человека» (часть 1) к все большей их конкретизации через осмысление человека, «живущего в природе и обществе» (часть 2), и, в конечном счете, к наиболее конкретным рассуждениям по вопросу, вынесенному в заголовок книги - «как же жить человеку на планете Земля», как обустроить, в частности, нашу страну, Россию (через создание некой теоретической модели и практических рекомендаций на эту тему). Рассматривается идея уровневого подхода, с 
Научные труды Московского гуманитарного университета 2018 № 2

учетом, однако, взаимосвязанности различных главных сфер бытия: мира чувственных восприятий, мира умопостигаемого и умосоздаваемого, мира трансцендентного.

Выделяются две категории людей в этом плане: верующих в существование Бога-Творца (среди них - представители различных религиозных конфессий и философы высшей категории) и не верящих в это (ибо это кардинально меняет цели и смыслы их деятельности). Причем, понятие «Бог-Творец» не несет смысла, придаваемого ему в каких - либо конкретных конфессиональных объединениях (требующих, в частности, соблюдения определенных обрядов и ритуалов поклонения). Оно употребляется для обозначения некоего всеобщего трансцендентного начала, способного и творить миры, которое иной раз называют Космическим Разумом, Вселенским Разумом и т. п., т. е. тем, что является предметом свободного обсуждения философов).

В главах «Что есть человек?», «Проблема жизни и диалектика жизни и смерти» выделяются суждения, где наука спорит с религией, прежде всего. Главные вопросы спора: загадка антропосоциогенеза (происхождения человека и общества) и соотнесение природного (биологического) и социального начала в человеке. Анализируются возможности целенаправленного синтеза основополагающих позиций: на примере учения Аристотеля, учений древних индийцев, (в т. ч. йога Патанджали), П. Тейяра де Шардена. Подчеркивается, что наука не дает четкого ответа и тут в разговор неизбежно вмешивается религия, мистика. Отмечается, что исследование тайны смерти ведет к анализу жизненных путей в этой жизни.

Делается вывод, что в любом случае, похоже, в конечном счете, надо переходить к рассмотрению общей картины мира, в формирование которой вносят свой вклад и наука, и религия, и мистика, и искусство, что автор и делает в следующей дискуссии.

В главе «Философские основы картины мира» в качестве таковых выделяются материализм и идеализм, теизм и атеизм (онтология), позна-ваемость, скептицизм и агностицизм (гносеология). Как раз с учетом этих основ (или ограничений) коротко анализируются ответы (очень разные у разных авторов) на фундаментальные проблемы и вопросы бытия. Отмечаются попытки соответствующего синтеза (К. Ясперс, П. Т. де Шарден). Как результат осмысления всех этих позиций, подчеркивается необходимость кропотливого изучения и т. н. философских категорий, реализуемая большинством крупнейших философов (автор рассматривает, как пример, категории: природа, бытие, пространство, время).

Излагается собственная точка зрения на картину мира и человека в этом мире, - она является сугубо философской, предполагающей свобод- 
ный исследовательский поиск истины, - не религиозной, хотя и опирающейся на концепции некоторых представителей различных религиозных конфессий, причем с позиций и экзотерики и эзотерики. Подчеркивается, что следует говорить, в конечном счете, о необходимости все большего синтеза принципов материализма и идеализма, оптимизма и скептицизма в познании, теизма и атеизма. Определившись в какой-то степени с наиболее общими мировоззренческими предпосылками, автор переходит к рассмотрению некоторых важнейших аспектов жизни человека в макромире: любовь и ненависть, красота и безобразие, добро и зло.

В последних главах $(10,11)$ анализируются размышления наших современников (менее философские, - в большей степени популистские): 1) о социуме и личности; 2) о т. н. «скрепах общества», - о его этнических корнях; о религии и атеистической вере; о поиске оптимальных конкретных форм общественного и государственного устройства; о Верховном Правителе.

В качестве вывода (Эпилог) дается ответ на поставленный в заголовке вопрос. Как жить человеку? Похоже, так, как он и живет, но в большей степени руководствуясь здравым смыслом, традициями, устоявшимися верованиями. Видимо, надо исходить из складывающейся обстановки на доступных анализу уровнях. Регуляцию жизнедеятельности осуществлять осторожно, - тем осторожней, чем обширнее подсистема (с оперативным анализом реакций). Стремиться увидеть, почувствовать при этом «некие» знаки трансцендентного и стараться руководствоваться ими.

На первый взгляд, вывод выглядит тривиальным. Однако следует учесть при этом все синтетическое знание, выделяемое в этой книге, куда достаточно гармонично вплетена вся священная история человечества (почерпнутая из философско-религиозных книг). Послесловие - невеселое и неутешительное (хотя трагический финал люди и пытаются отодвинуть подальше). Однако, все это - меры временные. Человечеству следует радикально изменить стратегию выживания и перейти от модели развития потребительской к модели экосберегающей. Но возможно ли это? Это большой вопрос, касающийся трактовки самой глубинной сущности человека и общей картины мира.

И как тут не вспомнить книгу проповедника Екклесиаста (философский реквием в прекрасном литературном изложении и переводе). Но даже в пессимизме нельзя быть до конца уверенным, - настоящий философ человек сомневающийся (Homo doubtful). Философия начинается с сомнения и заканчивается сомнением. Поэтому и книга заканчивается строками из древнегреческого гимна (пер. В. В. Вересаева): « Ты смертен человек поэтому живи, как будто каждый день последний для тебя, и в то же время так, как будто впереди еще полвека глубоко богатой жизни: законы боже- 
Научные труды Московского гуманитарного университета 2018 № 2

ские чти и духом радуйся. Нет блага выше!». По сути дела, это и есть центральная тема книги, отображенная и сюжетом на ее обложке.

В заключение отмечу, что такого рода творческие усилия способствуют и будут способствовать кардинальному изменению и совершенствованию российской постсоветской философии. Регулярное проведение мною Круглых столов «Философские диалоги» в Центральном Доме Литераторов в Москве и в Библио-Глобусе доказывает, что сегодня такого рода общение является достаточно актуальным. Об этом свидетельствует заполненный зал, в котором присутствуют не только известные профессионалы - философы, но и представители некоторых религиозных конфессий, деятели искусства, поэты, писатели, переводчики и иные вольные и смелые искатели истины. Именно философы по духу (независимо от того, есть у людей специальное философское образование или нет его) демонстрируют, как правило, желание и попытки наиболее глубокого осмысления фундаментальных проблем бытия: что есть человек, что есть окружающий его мир, каковы взаимоотношения между ними, что есть жизнь, что есть смерть, существует ли бессмертие души, свобода воли человека, что есть любовь и ненависть, милосердие и жестокость и т. д., - в чем, в конечном счете, смысл нашей жизни?

Все эти проблемы всегда находились (и ныне находятся) в поле зрения различных (и лучших) мыслителей, российских и зарубежных. Научная дискуссия, о которой пишут рецензенты книги, по сути дела не является чисто научной, - это некий «микст» (смешение жанров), где логика мысли сплетена с фантазией персонажей, художественным вымыслом, чего собственно и требует обсуждаемая тематика, на мой взгляд (как видно уже из оглавления книги). По сути дела, в философии - это путь древнего грека Платона, римского автора Лукиана, в России - М. М. Бахтина, В. С. Библера. В художественном изложении (совмещение пластов бытия) - своими предшественниками вижу М. А. Булгакова, Ф. Сологуба, В. Хлебникова, даже Ф. Достоевского («Сон смешного человека»), за рубежом - Данте Алигьери, Ч. Диккенс, Умберто Эко.

Главную задачу я вижу в том, чтобы о якобы не интересном поведать наиболее занимательно. С этой целью в книгу введены также фантастические литературные сюжеты с описанием прекрасных мест на Земле, в которых проходят заседания круглого стола по различным темам (поэтизированная проза): Подмосковье, Москва, Средиземноморье, страны западной Европы (как результат личных наблюдений автора). Этому способствуют, как предполагается, и переводы из трагедий У. Шекспира, сделанные автором, - по сути дела они, как камертон, задают звучание всей книги. (Кстати, обычно, в большинстве философских работ сегодня, все, как мне кажется, 
происходит наоборот, - философия в таком случае как бы омертвляется и становится не нужной никому, кроме профессионалов). У каждого из участников круглых столов есть своя точка зрения, а истина, как известно, рождается (а чаще, просто обсуждается) в диалоге, даже споре. И это особенно важно для нашего, я верю, неравнодушного сегодня общества.

\section{СПИСОК ЛИТЕРАТУРЫ}

Лосев, Ф. (1930) Диалектика мифа. М.

Дружинин, В. Ф. (2015) Как жить человеку на планете Земля? М.: РИПОЛ-Классик.

Дата поступления: 12.12.2017 2.

Дружинин Виктор Федорович - доктор философских наук, профессор, независимый автор; член Союза писателей России.

Druzhinin Viktor Fyodorovich, Doctor of Philosophy, Professor, Independent Author, Member, Writers' Union of Russia.

\section{Для цитирования:}

Дружинин В. Ф. К вопросу о качестве российской постсоветской философии [Электронный ресурс] // Научные труды Московского гуманитарного университета. 2018. №2. URL: http://journals.mosgu.ru/trudy/article/ view/691 (дата обращения: дд.мм.гг.). DOI: 10.17805/trudy.2018.2.4 